\title{
Process Mineralogy of Uranium Ore with High Fluorine
}

\author{
Liu-Lu CAI ${ }^{1, a^{*}}$, Xiao-Lan MO ${ }^{1, b}$, Shuang LIU ${ }^{1, c}$, Cheng-Ying ZHOU ${ }^{1, d}$ \\ and Wei QU ${ }^{1,}$ e
}

${ }^{1}$ National Engineering Laboratory of Biohydrometallurgy, General Research Institute of Nonferrous Metals, Beijing 100088, China

a *cailiulu_03@163.com, ${ }^{b}$ mxI0545@163.com, ${ }^{c}$ Ixx.future.8382@gmail.com,

d chengyingzhou@gmail.com, equwei7017@163.com

Keywords: Uranium minerals, Fluorine minerals, Bioleaching, Process mineralogy, MLA.

Abstract. Process mineralogy of a uranium ore which had U (0.22\%) and F (1.04\%) was investigated by modern SEM-based mineral liberation analysis (MLA) system and traditional process mineralogy research methods. The results indicate that traces of uranium minerals are mainly pitchblende, small amount of coffinite and brannerite in this ore. Pitchblende, coffinite and brannerite are fine and mainly embedded in quartz, muscovite and calcite. The content of pyrite and fluorite are $0.436 \%$ and $2.177 \%$ respectively. Fluorine minerals are mainly fluorite which is harmful to bioleaching. The content of quartz is $64.9 \%$, which is the main gangue in this ore. The characteristic of this ore is low content and fine particle size of pitchblende, low sulfide and high fluorine. Bioleaching won't have obvious advantages compare with conventional acid-leaching.

\section{Introduction}

Long-time, high-acid consumption and low leaching rate are the main problem of traditional acid heap leaching in Jinyuan uranium ore, south china. Mineralogy of uranium ore is the fundamental influencing factor of leaching process. Finding out the mineralogy influence factors of this ore is the basis to guide the advanced bioleaching technology of uranium. Mineral Liberation Analysis system (MLA) and traditional microscope, chemical analysis and XRD methods are employed to characterize the process mineralogy of this uranium ore.

\section{Materials and Methods}

The contents of U, Th, Fe, S, P, F, Ca, Mg, Al, Si are 0.22\%, 0.059\%, 1.09\%, 0.53\%, 0.012\%, 1.04\%, $3.26 \%, 0.36 \%, 3.90 \%$ and $35.69 \%$, respectively. Through crushing, grinding, screening and classification, samples are turned into six size fraction, which are $+0.150 \mathrm{~mm},-0.150+0.074 \mathrm{~mm}$, $-0.074+0.045 \mathrm{~mm},-0.045+0.038 \mathrm{~mm},-0.038+0.025 \mathrm{~mm}$ and $-0.025 \mathrm{~mm}$. Screened samples are embedded in resin to make 30mm diameter samples for microscope and MLA test.

SEM-based mineral liberation analysis (MLA) system, instead of traditional methods, is now widely used in the process mineralogy worldwide [1,2]. The system has been maturely used in the process mineralogy study of copper, lead, zinc, molybdenum, tungsten, gold, silver, platinum, palladium, vanadium, titanium ores [3-9].

\section{Results and Discussion}

\section{Mineralogy}

$\mathrm{XRD}$ result indicates that quartz is the main mineral in this ore. Quantitative mineralogy of this uranium ore is measured by MLA useing screening samples. Mineralogy of each fraction and the combined results are shown in Fig.1. The results indicate that traces of uranium minerals are mainly pitchblende, small amount of coffinite and brannerite in this ore. The contents of pitchblende, coffinite and brannerite are $0.47 \%, 0.03 \%$ and $0.004 \%$, respectively. Trace of thorium mineral is 
Thorite, of which the content is $0.003 \%$. Total content of pyrite is $0.44 \%$. Quartz, orthoclase and biotite are the main gangue minerals, of which the contents are $64.91 \%, 10.88 \%$ and $9.41 \%$, respectively. The content of fluorite is $2.18 \%$. High fluorite of the ore is harmful to bioleaching. The main acid-consumption minerals are calcite and dolomite, the content of which are $3.71 \%$ and $0.39 \%$. The content of clay mineral is low in this ore.

The contents of pitchblende and coffinite are nearly the same in each screened fraction. Fluorite and Biotite are mainly distributed in $-0.025 \mathrm{~mm}$ fraction. Quartz is the main mineral in each fraction. Calcite and dolomite are mainly distributed in $-0.074 \mathrm{~mm}+0.045 \mathrm{~mm}$ and $-0.025 \mathrm{~mm}$ fractions.

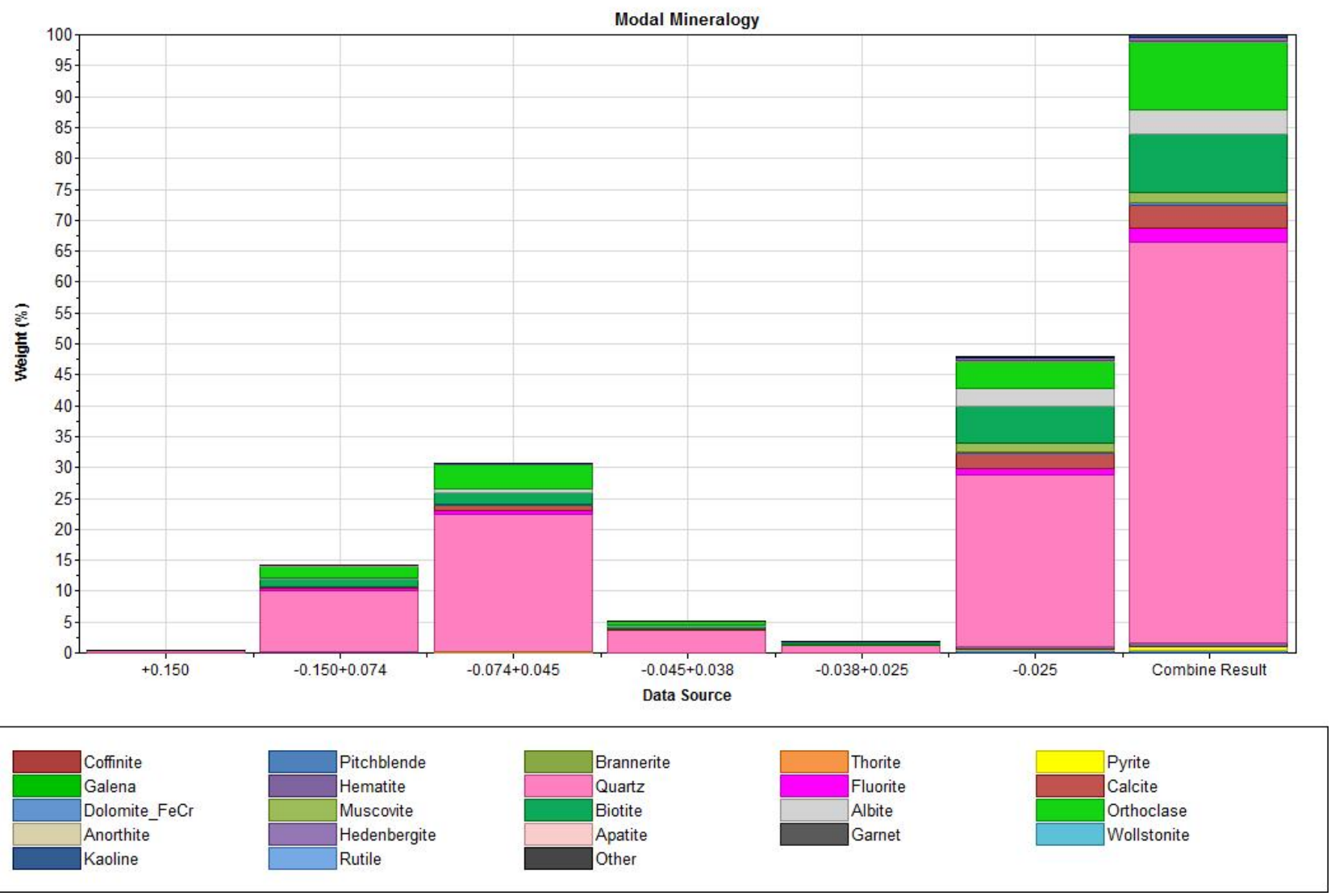

Fig.1. Mineralogy of Jinyuan uranium ore

\section{Elements Distribution}

Contents of $U$ element in pitchblende, coffinite and brannerite are $95.18 \%, 4.15 \%$ and $0.67 \%$, respectively. $99.93 \%$ of fluorine is distributed in fluorite while $0.07 \%$ in apatite. Pitchblende is the main valuable mineral and fluorite is the main harmful mineral in this ore.

\section{Characteristics of Uranium Minerals}

MLA system and traditional microscope are used in studying characteristic of uranium mineral in this case. Pitchblende is characterized as irregular granular and colloidal aggregates. It's shown as veins, scattered disseminated structure and mainly embed in quartz, muscovite and calcite, while rarely in pyrite and galena. Pitchblende co-exists with coffinite and brannerite. Part of the photos from SEM, MLA and microscope are shown in Fig.2. This figure indicates that MLA program can not only accurately measure the mineralogy of ore, but also show the characteristics of minerals well.

Particle size of uranium minerals is mainly distributed in $0.001 \mathrm{~mm}$ to $0.200 \mathrm{~mm}$, while $90 \%$ are under $0.030 \mathrm{~mm}$. 


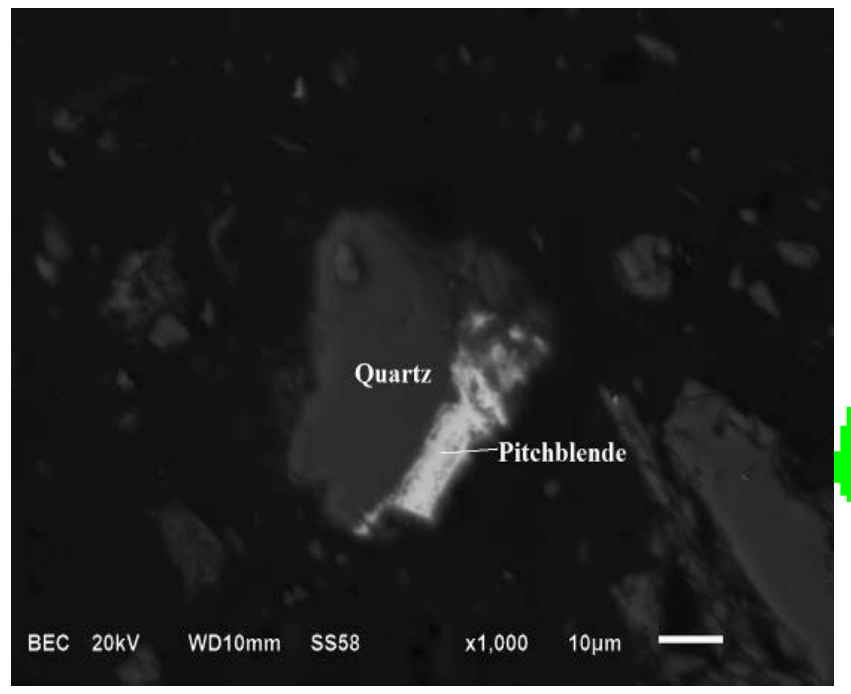

A

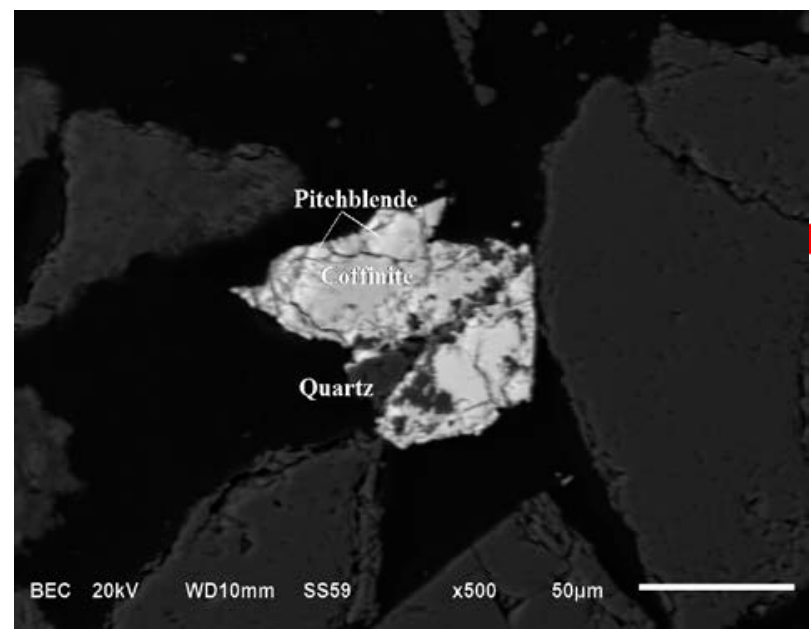

C

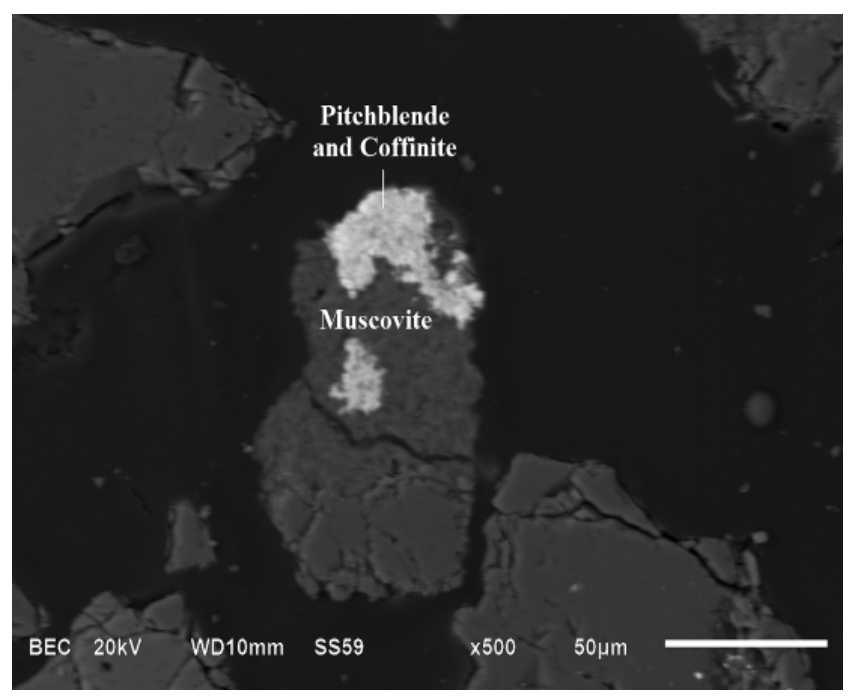

E

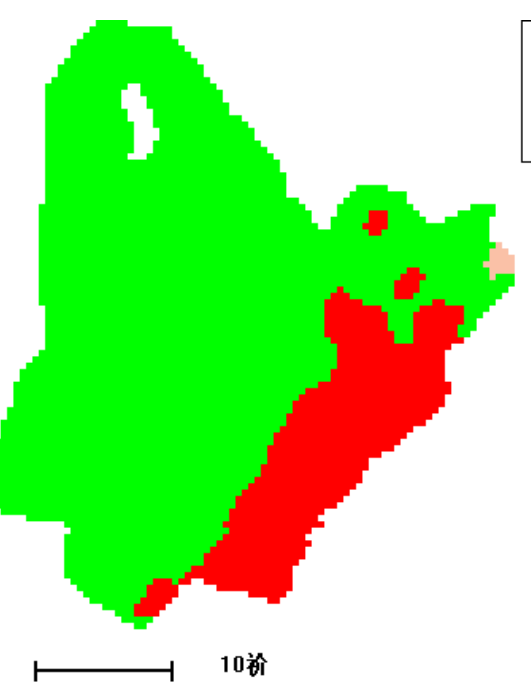

$13 \square$ Quartz : 3663

$2 \square$ Pitchblende : 871

$18 \square$ Biotite : 18

H 0.46 um size: $39 / 45$

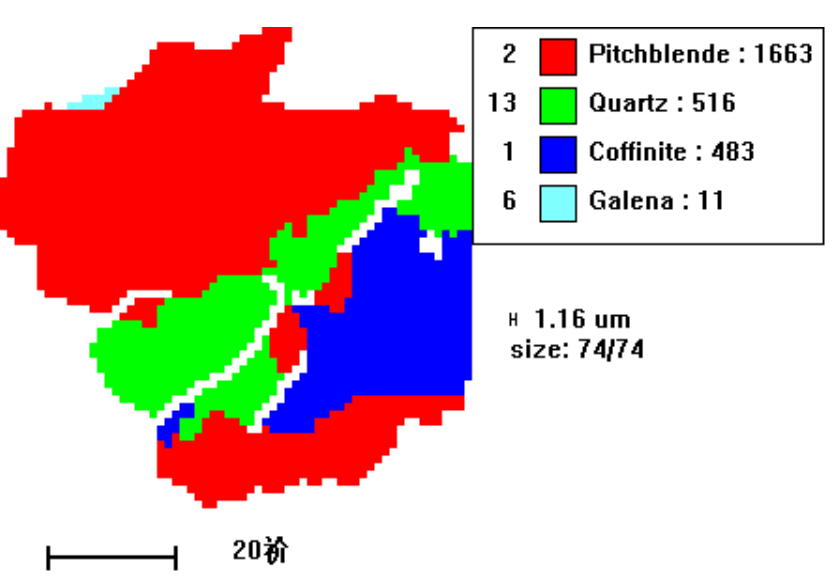

D

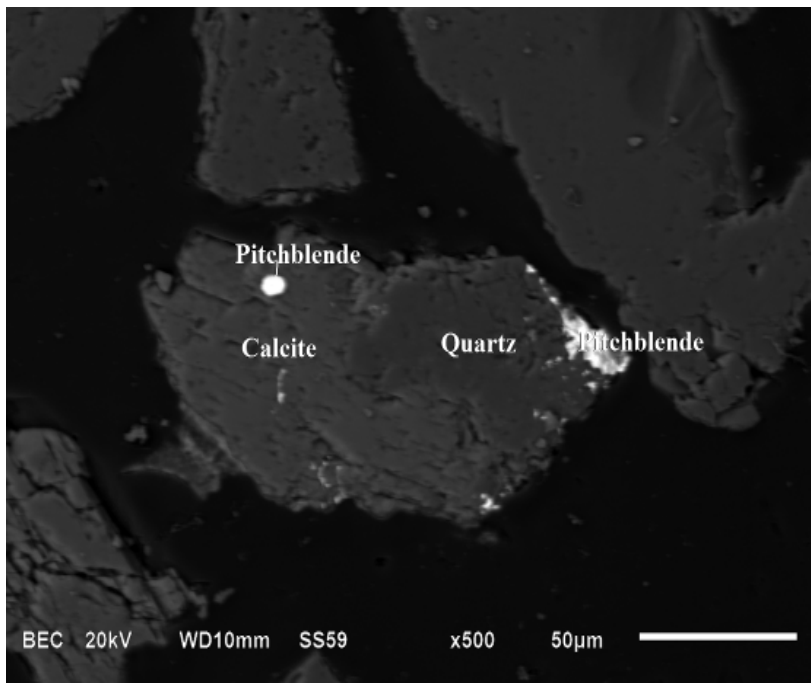

F 


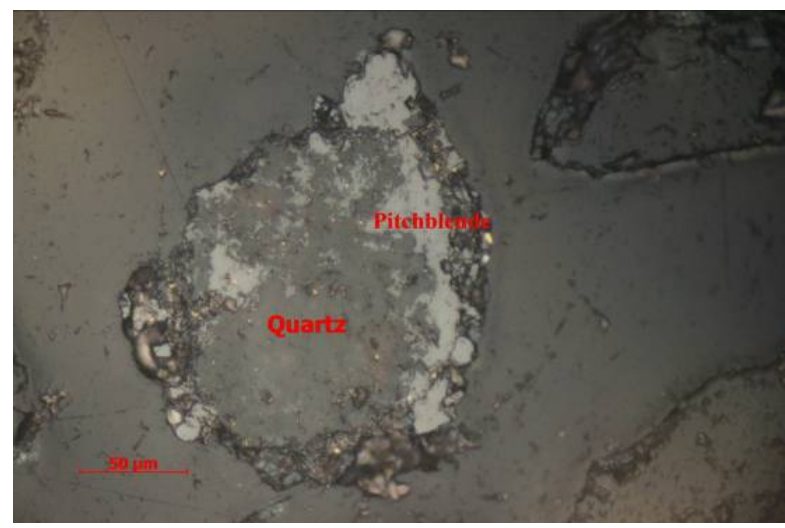

G

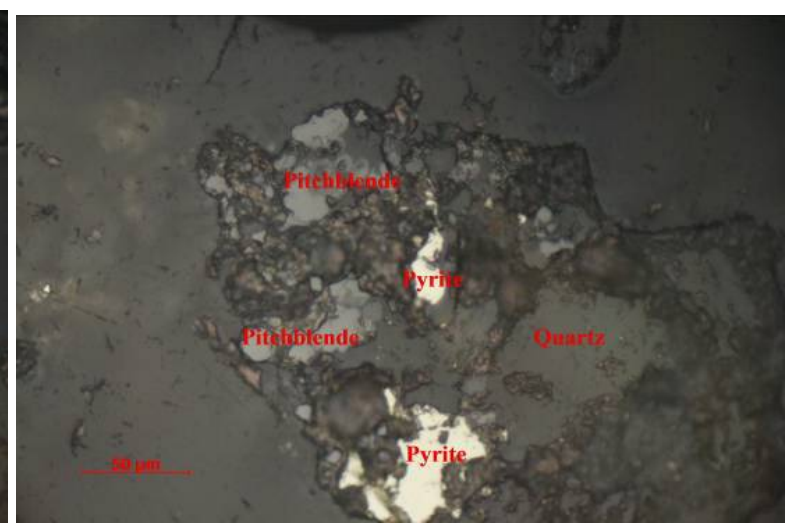

$\mathrm{H}$

Fig.2 A,B: Pitchblende in Quartz(SEM and MLA); C,D: Pitchblende and coffinite in Quartz(SEM and MLA); E: Pitchblende and Coffinite in Muscovite(SEM); F: Pitchblende in Calcite and Quartz(SEM); G,H :Pitchblende and pyrite in Quartz(microscope photo, 50×)

Liberation degree analysis of uranium minerals was conducted on sample at grinding particle size of $-0.074 \mathrm{~mm} 85 \%$, and result indicates fully liberated proportion of pitchblende, coffinite and brannerite are $35.05 \%, 9.92 \%$ and $5.49 \%$, respectively. Free surface of pitchblende in this sample $(-0.074 \mathrm{~mm} 85 \%)$ account for $64.79 \%$. The main intergrowth minerals are quartz accounting for $16.38 \%$ and followed by biotite and muscovite accounting for $7.67 \%$ together in surface.

Free surface of coffinite and brannerite in this sample $(-0.074 \mathrm{~mm} 85 \%)$ account for $26.42 \%$ and $28.61 \%$, respectively. This shows that it is difficult to achieve a high degree of liberation of pitchblende even through grinding means.

\section{Characteristics of Fluorine Minerals}

The fluorine minerals in this ore are mainly fluorite, the content of which is $2.18 \%$. Fluorite would generate hydrofluoric during acid leaching and increase the consumption of acid. The hydrofluoric have strong inhibition on the growth of bacteria, there for, fluoride-resistant bacteria strains is very necessary.

\section{Summary}

The results indicate that traces of uranium minerals are mainly pitchblende, small amount of coffinite and brannerite in this ore. $\mathrm{U}^{4+}$ in Pitchblende and part of fine pitchblende embedded in gangue mine is hard to leaching out.

The content of pyrite and fluorite were $0.436 \%$ and $2.177 \%$, respectively. Pyrite is very important in bioleaching process since it provides not only energy for bacteria but also oxidizer for uranium leaching. Low content of pyrite is not conducive to bacterial growth and uranium leaching. Fluorine minerals are mainly fluorite which is harmful to bioleaching.

The content of quartz is $64.9 \%$, which is the main gangue in this ore. The main acid-consumption minerals are calcite and dolomite, the content of which are $3.71 \%$ and $0.39 \%$. The content of clay mineral is low in this ore.

The characteristic of this ore is low content and fine particle size of pitchblende, low sulfide and high fluorine. Breeding fluoride-resistant bacteria are necessary for bioleaching process. Bioleaching won't have obvious advantages compared with conventional acid-leaching.

\section{Acknowledgements}

This work was supported by the National Natural Science Foundation of China (51404031). 


\section{References}

[1] Gu Y., Schouwstra R. P. and Rule C., The value of automated mineralogy, J, Minerals Engineering. 58 (2014) 100-103.

[2] Peng M. S., Liu X.W., Liu Y. and Yang Z.J., The Main Advances of Process Mineralogy in China in the Last Decade, J, Bulletin of Mineralogy, Petrology and Geochemistry. 31 (2012) 210-217.

[3] Cai L.L., Liu S., Liu X., Mo X.L., Zhou C.Y. and Qu W., Process Mineralogy of Low-grade Sulfide Copper Ore Based on Mineral Liberation Analysis System , A, International Conference on Energy and Environmental Protection[C] .Shenzhen, China(2015).

[4] Jiang C.L., Qu S.S .and Wang L.Z., Cu-Pb-Zn-Ag Occurrence State and Mineralogical Factors Affecting Mineral Processing for A Polymetallic Ore from Inner Mongolia, J, Mining and Metallurgical Engineering, 35(2015) 41-44(In Chinese)

[5] LI B., Liang D.Y. and Zhang L.L., Process Mineralogy of Quartz Veinlet-type Complex Tungsten-Molybdenum Polymetallic Ore, J, China Tungsten Industry, 5(2013) 28-31(In Chinese)

[6] Cai L.L., Liu S., Li W.J., Zhou C.Y. Qu W. and Song Y.S.. Process mineralogy of Jinshan gold ore based on mineral liberation analysis system, A, International Conference on Advances in Energy and Environmental Science[C], Guangzhou, China, 2014

[7] Fang X.H., Zheng X.H., Chen W.L., Zeng H.Y. and Zhang S. Mineralogy of a Silver-bearing Polymetallic Ore in Fujian and Silver Efficiently Recovering, J , Nonferrous Metals Engineering, 5 (2015) 49-53(In Chinese)

[8] Fang M.S., Wang L. and Xiao Y.W. Study on process mineralogy study for Pt-Pd ore in Africa[J].Mining and Metallurgy, 23 (2014) 72-76(In Chinese)

[9] Liu T.T., Yuan W., Zhang C.and Jin Z.Q. Mineralogical characterization of the canadium titano magnetite in Canada [J]. Multipurpose Utilization of Mineral Resources, 3 (2014) 51-54(In Chinese) 